\title{
SURVEY OF THE BAT FAUNA, DESERT NATIONAL WILDLIFE REFUGE, NEVADA
}

\author{
Thomas J. O’Shea ${ }^{1,2}$, Christy Klinger ${ }^{3}$, Lindsay A. Smythe ${ }^{4,5}$, Laura Wilkinson ${ }^{1}$, and John P. Dumbacher ${ }^{1}$
}

Abstract-We conducted a survey of the bat fauna of Desert National Wildlife Refuge (DNWR) in Nevada during 2008-2014. Our objectives were (1) to determine the species present at DNWR by mist-netting at likely bat drinking areas; (2) to compare the bat fauna at White Spot Spring at DNWR to the fauna documented there in 1962-1967; and (3) to assess the possible importance of artificial water sources to bats on this highly arid landscape in relation to an ongoing drought. We captured 480 bats of 10 species in mist nets over drinking water sources; species identifications are documented by voucher specimens. In order of frequency of capture, species and numbers of individuals captured were as follows: canyon bat (Parastrellus hesperus), 223; combined California myotis and western small-footed myotis (Myotis californicus/M. ciliolabrum), 157; long-legged myotis (Myotis volans), 55; long-eared myotis (Myotis evotis), 12; Townsend's big-eared bat (Corynorhinus townsendii), 12; fringed myotis (Myotis thysanodes), 10; pallid bats (Antrozous pallidus), 7; big brown bats (Eptesicus fuscus), 3; and Yuma myotis (Myotis yumanensis), 1. California myotis and smallfooted myotis could not be reliably distinguished in the field because many individuals were intermediate in identifying characters. The abundance-based Jaccard's community similarity index for the bat community at White Spot Spring in April and July 2013-2014 compared with that from about 50 years earlier (O'Farrell and Bradley 1970) was 0.99 (SE bootstrap 0.02), indicating negligible change. Despite an ongoing severe drought, positive evidence for female reproduction was evident in July 2014. We suspect that DNWR could not sustain current levels of reproduction in bats without suitable drinking water sources.

Resumen.-Realizamos un monitoreo de la fauna de murciélagos del Refugio del Desierto de la Reserva Nacional (RBSN) en Nevada durante 2008-2014. Nuestros objetivos fueron: (1) determinar, con el uso de redes de niebla, las especies presentes en RBSN en zonas de acceso a agua; (2) comparar la fauna de murciélagos en el manantial White Spot Spring dentro de RBSN con la fauna documentada allí entre 1962-1967; (3) evaluar la posible importancia de las fuentes de agua artificiales para los murciélagos en este paisaje tan árido en relación con la actual sequía. Capturamos 480 murciélagos de 10 especies con redes de niebla sobre las fuentes de agua, documentados por especímenes de muestra. En orden de frecuencia de captura, las especies y el número de individuos capturados fueron: murciélagos del cañón (Parastrellus hesperus), 223; combinados, el murciélago de California y el murciélago de patas cortas del oeste (Myotis californicus/M. ciliolabrum), 157; murciélago de patas largas (Myotis volans), 55; murciélago orejudo (Myotis evotis), 12; murciélagos orejudos de Townsend (Corynorhinus townsendii), 12; murciélagos bordados (Myotis thysanodes), 10; murciélagos pálidos (Antrozous pallidus), 7; murciélagos marrones (Eptesicus fuscus), 3; y murciélagos Yuma (Myotis yumanensis), 1. Los murciélagos de California y los de patas cortas no pudieron distinguirse de forma fiable en el campo debido a que muchos individuos mostraban características intermedias. La abundancia basada en el Índice de Similitud de Jaccard para la comunidad de murciélagos en el manantial White Spot Spring en abril y julio de 2013-2014, en comparación con la de unos 50 años antes (O’Farrell y Bradley 1970), fue de 0.99 (Error estándar con bootstrap 0.02), lo que indica un cambio muy pequeño. A pesar de una grave sequía en curso, encontramos evidencia positiva de la reproducción de las hembras en julio de 2014. Sospechamos que RBSN no podría mantener los niveles actuales de reproducción de los murciélagos sin fuentes de agua adecuadas las.

The composition of the bat communities of many public lands remains poorly understood. Historically, inventory and management for bats on most national wildlife refuges was a lower priority than for other species, but in recent decades there has been increasing concern for bat conservation. Calls have been issued for greater management for bats throughout the
United States Fish and Wildlife Service (USFWS) refuge system (Dixon et al. 2013). A first step in addressing these concerns is to gain basic knowledge about the species of bats present on each refuge. We conducted a survey of the bats of the Desert National Wildlife Refuge (DNWR), Lincoln and Clark counties, Nevada, in 2008-2014. DNWR is the largest

\footnotetext{
${ }^{1}$ California Academy of Sciences, San Francisco, CA 94118

${ }^{2}$ Present address: Box 65, Glen Haven, CO 80532. E-mail: osheatj@msn.com

3 Nevada Department of Wildlife, 4747 Vegas Drive, Las Vegas, NV 89108.

${ }^{4}$ United States Fish and Wildlife Service, Desert National Wildlife Refuge, 16001 Corn Creek Road, Las Vegas, NV 89124

${ }^{5}$ Present address: USDA Forest Service, 5075 N. Hwy. 89, Flagstaff, AZ 86004.
} 


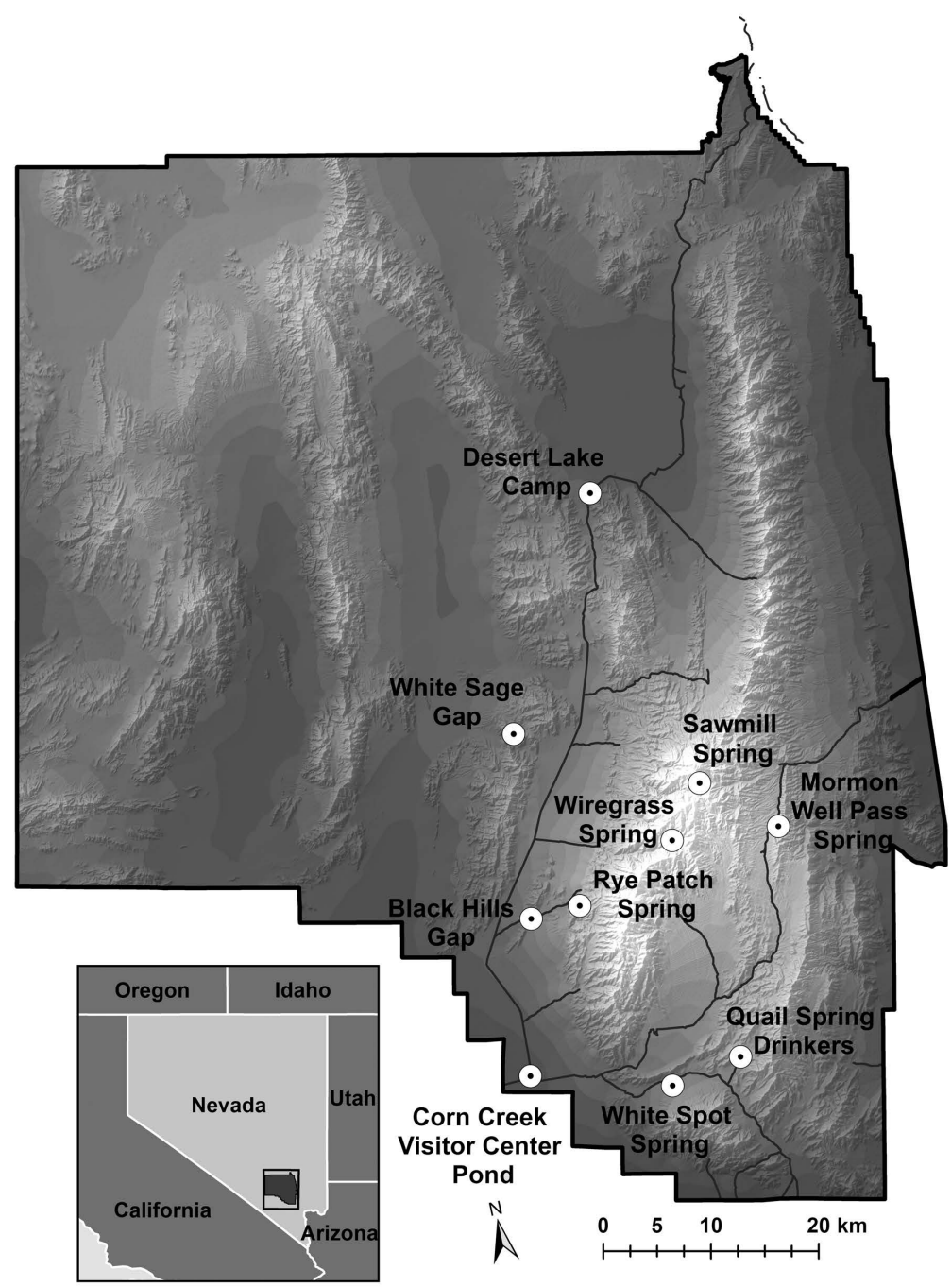

Fig. 1. Desert National Wildlife Refuge (DNWR), with locations where bats were captured. See Appendix 1 and text for additional details on capture sites. The western half $\left(3300 \mathrm{~km}^{2}\right)$ of the $6540-\mathrm{km}^{2}$ refuge is shared with the Nevada Test and Training Range, where access is restricted due to military activity.

USFWS refuge in the 48 contiguous states (http://www.fws.gov/refuge/desert/), but no recent published information is available about bats on the DNWR. Our objectives were (1) to determine the species present on the refuge by mist-netting at likely bat drinking areas and capturing, identifying, and releasing bats, including documenting the fauna through voucher specimens; (2) to compare the bat fauna at White Spot Spring at DNWR to the fauna documented there by O’Farrell and Bradley (1970) from 1962 to 1967 for indications of major changes over the past 47-52 years; and (3) to assess the likely importance of artificial water sources to bats on this highly arid landscape in light of an ongoing spring/early summer drought in 2014.

We captured bats in 2008-2014 at DNWR using mist nets set at ground level over 8 water sources developed and maintained to ensure regular availability of water for wildlife (Fig. 1, Appendix 1). Most sampling took place in 2012-2014, but we also sampled on 2 nights each year in 2008 and 2009 (Appendix 1). We also reported incidental captures of 2 bats at 
terrestrial locations other than water sources (Appendix 1). Seven of the 8 water sources were primarily seeps, with surface areas of water accessible to bats approximately $1.3 \mathrm{~m}^{2}$ or less. The highly developed Corn Creek Visitor Center Pond had a surface area of approximately $1500 \mathrm{~m}^{2}$. We sampled every available site with water within $1 \mathrm{~km}$ of primitive roads (many developed sites are near roads for ease of maintenance) that was not restricted due to military activity. We knew of no other natural perennial sources of water on DNWR that were accessible to us at the time of our study. We sampled at the surface and at the approaches to the small water sources using 1 or 2 mist nets (50 denier, $38 \mathrm{~mm}$ mesh, 4 shelves; Avinet, Dryden, NY), $2.6 \mathrm{~m}$ high and varying in length from $2.6 \mathrm{~m}$ to $6.0 \mathrm{~m}$. At the Corn Creek Visitor Center Pond, we set 3-4 mist nets $2.6 \mathrm{~m}$ high and varying in length from 6 to $9 \mathrm{~m}$ around the perimeter of the pond (not directly across), including 1-2 threetiered stacked nets (Bat Conservation and Management Inc., Carlisle, PA) varying from 6 to $9 \mathrm{~m}$ in length and extending to $7.8 \mathrm{~m}$ above ground level. Sampling with mist nets over water sources in arid areas has been a standard technique for inventory of bats in Nevada (e.g., Ports and Bradley 1996, Szewczak et al. 1998, Kuenzi et al. 1999, Hall 2000), and acoustic sampling at the nearby Nevada Test Site has shown that bat activity away from watering sites is very low (Hall 2000). However, relative abundances of species that are derived from mist-net sampling have inherent biases and may not reflect true abundance of species in the local bat community. Information about sampling locations, elevations, land cover types, dates, species, and numbers of individuals captured is given in Appendix 1. Other possible watering sites were investigated in 2012-2014 but were found to be dry: Upper $(36.42602 \mathrm{~N}, 115.22304 \mathrm{~W})$ and Lower $(36.42867 \mathrm{~N}, 115.22810 \mathrm{~W})$ White Blotch Springs, Gass Spring (36.42607N, 115.16472W), and Perkins Spring (36.70456 N, $115.16579 \mathrm{~W})$. The spring and early summer drought in 2014 was severe, with mean monthly precipitation at the Corn Creek site dropping from 1940-2013 averages of 7.9, 4.3 , and $2.8 \mathrm{~mm}$ in April, May, and June to 1.0, 0.3 , and $0.0 \mathrm{~mm}$ during the same months of 2014 (National Climatic Data Center, http:// www.ncdc.noaa.gov/cdo-web/search; Western
Regional Climatic Center, http://www.wrcc .dri.edu/cgi-bin/cliMAIN.pl?nv2243).

Each captured bat was identified to species, and its sex, relative age (adult or volant juvenile), and reproductive status were determined using standard field assessment techniques (Brunet-Rossinni and Wilkinson 2009, Racey 2009). Females were categorized as lactating, postlactating, or nonreproductive during July 2013 and 2014 (external indications of reproductive status are most discernible in July). Voucher specimens were preserved as museum skins and skulls, with liver and muscle samples preserved in ethanol in the field and stored frozen at the California Academy of Sciences (CAS). We also collected a single 4-mm round biopsy punch from wing membranes of a subsample of individuals prior to release. This is a standard nonlethal procedure used in obtaining tissue samples from bats for future genetic studies (Simmons and Voss 2009). Bat capture, biopsy, and euthanization followed guidelines of the American Society of Mammalogists (Sikes et al. 2011), and protocols were reviewed and approved by the CAS Institutional Animal Care and Use Committee (approval \#2012-03). Problems arose in distinguishing individuals of 2 small species of Myotis: the California myotis ( $M$. californicus) and the western small-footed myotis (M. ciliolabrum). Distinguishing these 2 species (even in hand) can be very difficult (e.g., Verts and Carraway 1998, Rodriguez and Ammerman 2004), although in some areas external characters may more easily allow specific identification (Constantine 1998). Due to potential biases that might be realized through misidentification of these 2 species, we followed the procedure of Hall (2000), Chung-MacCoubrey (2005), and Geluso and Geluso (2012) and combined the species as M. californicus/M. ciliolabrum. Below we provide evidence that both species were present at DNWR, but the accuracy of identification of every individual captured and released is uncertain. We recorded ultrasonic echolocation calls of 16 individual $M$. californicus $/ M$. ciliolabrum while hand-held and immediately following release. These 2 species are typically distinguishable based on the terminal frequency of their frequency-modulated (FM) sweeps (O'Farrell 1997, O'Farrell et al. 1999, Gannon et al. 2001). Recordings at DNWR were made with the Echometer EM3 recorder 
TABLE 1. Species, numbers taken, and relative abundances $(\%)$ of bats documented at White Spot Spring, Desert National Wildlife Refuge, Nevada, during April and July 1962-1967 (O'Farrell and Bradley 1970) and in April and July 2013-2014.

\begin{tabular}{lcc}
\hline & $\begin{array}{c}\text { Captures in } \\
\text { April and July } \\
1962-1967 \\
\text { Species }\end{array}$ & $\begin{array}{c}\text { Captures in } \\
\text { April and July } \\
2013-2014 \\
(10 \text { nights })\end{array}$ \\
\hline $\begin{array}{l}\text { Parastrellus hesperus }) \\
\text { Myotis californicus/ }\end{array} \quad 203(85.7 \%)$ & $57(59.4 \%)$ \\
$\quad$ M. ciliolabrum & $27(11.4 \%)$ & $34(35.4 \%)$ \\
Antrozous pallidus & $3(1.3 \%)$ & $4(4.2 \%)$ \\
Corynorhinus & $1(<1 \%)$ & $1(1.0 \%)$ \\
$\quad$ townsendii & $1(<1 \%)$ & 0 \\
Myotis volans & $1(<1 \%)$ & 0 \\
Myotis yumanensis & $1(<1 \%)$ & 0 \\
Eptesicus fuscus & 237 & 96 \\
ToTAL & & \\
\hline
\end{tabular}

(Wildlife Acoustics, Inc.) and stored digitally as WAV files. Spectral analysis was performed in Hanning windows by using spectrograms, oscilloscope tracings, and power spectrum analysis features of Call Viewer software (Skowronski and Fenton 2008).

To assess possible long-term changes in the bat fauna, we compared the similarity of the bat community between mist-net surveys at White Spot Spring during April and July 1962-1967 (O'Farrell and Bradley 1970) with combined results collected during mist-net surveys in April and July 2014 and July 2013. We computed the abundance-based Jaccard's index of community similarity (Chao et al. 2006) using Program SPADE with 500 bootstrap replications (Chao and Shen 2010). This index varies from 0 (indicating no similarity) to 1.0 (complete similarity). O'Farrell and Bradley (1970) did not distinguish between M. californicus and M. ciliolabrum (then under the name $M$. subulatus) in their sampling, so for this analysis of similarity we treated captures of these 2 species as combined $M$. californicus/M. ciliolabrum.

We captured 480 bats of 10 species at DNWR in 2008-2014. Species and numbers captured (in parentheses after scientific names) in order of relative abundance were as follows: canyon bat (Parastrellus hesperus), 223; combined California myotis and western small-footed myotis (M. californicus/M. ciliolabrum), 157; long-legged myotis (Myotis volans), 55; long-eared myotis (Myotis evotis), 12; Townsend's big-eared bat (Corynorhinus townsendii), 12; fringed myotis (Myotis thysan- odes), 10; pallid bat (Antrozous pallidus), 7; big brown bat (Eptesicus fuscus), 3; and Yuma myotis (Myotis yumanensis), 1. Voucher specimens for 8 species (34 as skins and skulls with corresponding liver and muscle samples, 3 as carcasses in fluids, and 24 as small biopsies of wing tissues from bats released at capture) are available through the CAS for future studies.

Several of the bats categorized as combined M. californicus/M. ciliolabrum were intermediate in characters that others suggest allow distinguishing between species, but some clearly had distinctive attributes of either $M$. californicus or M. ciliolabrum. This characterization was based on recordings of terminal frequencies of 16 hand-held bats using criteria of Gannon et al. (2001) and O'Farrell et al. (1999), forearm measurements of 35 individuals compared with those reported by Constantine (1998), and skull flattening and cranial measurements of 15 voucher specimens compared with data reported by van Zyll de Jong (1984) and Constantine (1998). However, exsertion of the tail tip reported by Constantine (1998) did not consistently sort with other characters, and bivariate plots of cranial measurements suggested as diagnostic by Bogan (1974) and Hoffmeister (1986) also did not clearly separate our voucher specimens. Identification of these species throughout their ranges remains problematic. Analysis of mitochondrial DNA samples from other areas of the western United States also failed to reveal distinct groupings consistent with any concordant morphological separation (Rodriguez and Ammerman 2004). Further research, particularly including studies of nuclear genes, may be required to definitively assign our specimens to species.

The abundance-based Jaccard's similarity index for the bat community at White Spot Spring in April and July 2013-2014 compared with that from about 50 years earlier (O’Farrell and Bradley 1970) was 0.99 (SE bootstrap $0.02)$, indicating little change. The number of individual bats caught per night was similar between the 2 periods (23.7 bats in 1962-1967 and 20.0 bats in 2013-2014). The rank order of relative abundances also was similar (Table 1), with canyon bats being the most abundant, followed by M. californicus/M. ciliolabrum and pallid bats a distant third with a very low number of captures of all other species (Table 1). One of the 3 additional species documented 
by single captures in April and July 19621967 was possibly a vagrant. Yuma myotis are very colonial, and were they resident, greater numbers of captures would seem likely. In addition, Yuma myotis are characteristically found in habitats along running water in creeks, streams, and rivers. Overall, the list of species documented at DNWR in 2008-2014 compared with the year-round list compiled in 1962-1967 at White Spot Spring (see O'Farrell and Bradley 1970) differed only in captures of long-eared myotis in 2008-2014 (at elevations $>1000 \mathrm{~m}$ higher than White Spot Spring) and a lone Brazilian free-tailed bat (Tadarida brasiliensis) in May 1962-1967. Brazilian free-tailed bats are typically captured at waterbodies with greater surface areas than are availale at White Spot Spring (their likely rarity at DNWR also was evident from lack of capture at the larger Corn Creek Visitor Center pond during our study).

Although intensity of sampling at higherelevation habitats was more limited than at lower-elevation sites (Appendix 1), species habitat occurrences were consistent with previous reports for Nevada and elsewhere in the arid southwestern United States (e.g., Hall 1946, Hall 2000, Hoffmeister 1986). Species captured primarily at the 4 sites situated at $1890 \mathrm{~m}$ and higher in pinyon-juniper woodland and mixed conifer forest habitats (Mormon Well Pass Spring, Rye Patch Spring, Sawmill Spring, and Wiregrass Spring) rather than at lower-elevation habitats included $M$. evotis, M. thysanodes, and M. volans. These 3 species are also categorized as poorer osmoregulators compared with some of the species we captured at lower-elevation desert habitats, such as A. pallidus and P. hesperus (Geluso 1978). Availability of drinking water at DNWR may be especially important for these species. We did not capture any tree bats such as Lasionycteris noctivagans or Lasiurus cinereus, which are also poorer osmoregulators (Geluso 1978), although they may occur at DNWR, especially at higher elevations and perhaps during migration. E.R. Hall (1946) presents single records for $L$. noctivagans at Hidden Forest and Corn Creek at DNWR, and D.B. Hall (unpublished data) captured a single $L$. noctivagans along with 3 long-eared myotis and 2 pallid bats in a small (approximately $1.0-1.5 \mathrm{~m}^{2}$ surface area) temporary rain-filled tinaja at Hidden Forest (elevation approxi- mately $2400 \mathrm{~m})$ on 15 May 2009. D.B. Hall (unpublished data) also recorded echolocation calls of bats, including $L$. cinereus, M. californicus, and M. ciliolabrum at Hidden Forest on 15 May 2009. Both L. noctivagans and $L$. cinereus have been captured relatively rarely elsewhere in Nevada, and mostly at higherelevation localities with greater access to drinking water and more deciduous vegetation (Ports and Bradley 1996, Kuenzi et al. 1999, Hall 2000). Tree bats also do not appear to concentrate in our study region during migration (Cryan 2003). The higher-elevation watering sites with limited water surface areas at DNWR may be less approachable for these higher aspect-ratio, less maneuverable species.

Despite the drought, evidence of reproduction was detected in July 2014. Sixty-three of $66(95.5 \%)$ adult female canyon bats captured between 22 and 26 July were lactating (62) or postlactating (1). All of the adult female $M$. californicus/M. ciliolabrum captured from 22 to 28 July were reproductive, with 44 of 48 (91.7\%) lactating and the remaining 4 (8.3\%) postlactating. Three of $7(42.9 \%)$ adult female long-legged myotis captured on 24 and 28 July at Mormon Well spring were lactating while 4 were nonreproductive. Two of $3(66 \%)$ fringed myotis captured on the same dates at that location also were lactating and one was nonreproductive. Also in July 2014, we captured volant juveniles (young born earlier in 2014) of the following 4 species (numbers of individuals in parentheses): pallid bat (1), Myotis californicus/M. ciliolabrum (4), long-legged myotis (3), and canyon bat (4). During July 2013 (prior to the drought year), we captured 35 adult female canyon bats, 21 adult female M. californicus $/ M$. ciliolabrum, and 3 adult female fringed myotis, all of which were lactating, indicating comparable levels of reproduction of bats captured over water in both years.

Our natural history observations support the hypothesis that bats at DNWR heavily use the limited number of small springs for drinking water. Unless evidence to the contrary is presented, these springs should be maintained so that water is always available and surface mats of algae are removed. Lactating female bats use more drinking water than males and nonreproductive females (Adams and Hayes 2008, Adams 2010). A large proportion of the bats we captured (175 of 183 females of 7 species, see above) over water in July 2013 
and 2014 were lactating. Other natural history observations also suggest that it is possible that DNWR might not reliably maintain large numbers of reproducing female bats without these permanent watering places, particularly during droughts. For example, we captured bats at Mormon Well spring in pinyon-juniper woodland habitat on 24 and 28 July 2014 . On 24 July conditions were dry due to the preceding long spring and early summer drought. On 28 July captures took place during a period of rain from summer storms that had begun on the DNWR on 26 July. Standing water was common in temporary pools in the pinyon-juniper woodlands and transition zones on 28 July but nonexistent on 24 July. Netting results on the 2 dates differed substantially in numbers of bats captured and species composition: 76 bats of 6 species $(91 \%$ adults) were captured on 24 July, whereas only 9 bats of 3 species ( $89 \%$ adults) were captured on 28 July. On 24 July we captured 20 P. hesperus (17 lactating females), a more typically lowland, desert species. On 28 July we captured none. It is possible that in the absence of surface water, lowland species may have been travelling farther upland to drink. (On 19 June 2013, we captured no P. hesperus out of 69 bats captured at this site). Patterns of greater capture success over watering places at times when rainfall is low also have been documented in New Mexico (Geluso and Geluso 2012).

Some watering sites at DNWR may not have enough surface water available to be heavily used by bats. For example, the 2 "drinkers" at Quail Spring (Appendix 1) are designed to provide water sources for ungulates, but each provides a surface area of about $0.1 \mathrm{~m}$ or less. We netted over both drinkers on 10 April and 27 July 2014 but unlike at the other small springs, we captured no bats and saw no bats attempting to drink. Similar findings were reported for artificial water sources at the highly arid Kofa National Wildlife Refuge in southwestern Arizona, where few bats were captured and few were seen flying or attempting to drink at water sources with $<1.2 \mathrm{~m}^{2}$ water surface area (Rabe and Rosenstock 2005). We follow the recommendations made in that study (Rabe and Rosenstock 2005) and suggest that to enhance use of an artificial water body by bats at DNWR, the surface area should be larger than that of some existing small drinkers, and the water level within should be nearly as high as the enclosing metal rim. Efforts should be made to ensure presence of water year-long at as many sites as possible, especially during drought. Long-term threats to water availability such as more intensive droughts due to climate change and increased use of ground water by regional land development will require additional management planning.

\section{ACKNOWLEDGMENTS}

Bats were sampled and collected under state of Nevada Permit S37293 issued to JPD, California Academy of Sciences. Galen Rathbun, Amy Sprunger, Maureen Flannery, Rob and Luke Peloquin, and the staff of DNWR gave much support and help in the field. Discussions with Mike Bogan and Loren Ammerman contributed useful insights into identification problems with M. californicus and M. ciliolabrum. We thank Lauren Scheinberg for preparing the study area map and Derek Hall for providing unpublished information.

\section{Literature Cited}

ADAMS, R.A. 2010. Bat reproduction declines when conditions mimic climate change projections for western North America. Ecology 91:2437-2445.

AdAms, R.A., AND M.A. HAYEs. 2008. Water availability and successful lactation by bats as related to climate change in arid regions of western North America. Journal of Animal Ecology 77:1115-1121.

Bogan, M.A. 1974. Identification of Myotis californicus and M. leibii in southwestern North America. Proceedings of the Biological Society of Washington $87: 49-56$.

Brunet-Rossinni, A.K., AND G.S. Wilkinson. 2009. Methods for age estimation and the study of senescence in bats. Pages 315-325 in T.H. Kunz and S. Parsons, editors, Ecological and behavioral methods for the study of bats. 2nd edition. Johns Hopkins University Press, Baltimore, MD.

Chao, A., R.L. Chazdon, R.K. Colwell, and T.-J. Shen. 2006. Abundance-based similarity indices and their estimation when there are unseen species in samples. Biometrics 62:361-371.

Chao, A., And T.-J. Shen. 2010. User's Guide for Program SPADE (Species Prediction and Diversity Estimation). http://chao.stat.nthu.edu.tw/wordpress/ wp-content/uploads/software/SPADE_UserGuide .pdf

Chung-MacCoubrey, A.L. 2005. Use of pinyon-juniper woodlands by bats in New Mexico. Forest Ecology and Management 204:209-220.

Constantine, D.G. 1998. An overlooked external character to differentiate Myotis californicus and Myotis ciliolabrum (Vespertilionidae). Journal of Mammalogy 79:624-630. 
Cryan, P.M. 2003. Seasonal distribution of migratory tree bats (Lasiurus and Lasionycteris) in North America. Journal of Mammalogy 84:579-593.

Dixon, M.D., K. Heist, and K. Tinsley. 2013. The state of bats in conservation planning for the National Wildlife Refuge System, with recommendations. Journal of Fish and Wildlife Management 4:406-422.

Gannon, W.L., R.E. Sherwin, T.N. DeCarvalho, and M.J. O’FARRELL. 2001. Pinnae and echolocation call differences between Myotis californicus and M. ciliolabrum (Chiroptera: Vespertilionidae). Acta Chiropterologica 3:77-91.

GeLuso, K.N. 1978. Urine concentrating ability and renal structure of insectivorous bats. Journal of Mammalogy 59:312-323.

Geluso, K.N., AND K. Geluso. 2012. Effects of environmental factors on capture rates of insectivorous bats, 1971-2005. Journal of Mammalogy 93:161-169.

HALL, D.B. 2000. Bat monitoring on the Nevada test site in south central Nevada. Transactions of the Western Section of the Wildlife Society 36:8-14.

HaLL, E.R. 1946. Mammals of Nevada. University of California Press, Berkeley, CA.

Hoffmeister, D.F. 1986. Mammals of Arizona. University of Arizona Press and Arizona Game and Fish Department, Tucson, AZ.

Kuenzi, A.J., G.T. Downard, and M.L. Morrison. 1999. Bat distribution and hibernacula use in west central Nevada. Great Basin Naturalist 59:213-220.

Lowry, J.H, JR., R.D. Ramsey, K. Boykin, D. Bradford, P. Comer, S. Falzarano, W. Kepner, J. Kirby, L. Langs, and J. Prior-Magee, ET AL. 2005. Southwest Regional Gap Analysis Project: Final Report on Land Cover Mapping Methods. RS/GIS Laboratory, Utah State University, Logan, UT. http://earth.gis .usu.edu/swgap/swregap_landcover_report.pdf

O'FARRELL, M.J. 1997. Use of echolocation calls for the identification of free-flying bats. Transactions of the Western Section of the Wildlife Society 33:1-8

O'FarRell, M.J., AND W.G. Bradley. 1970. Activity patterns of bats over a desert spring. Journal of Mammalogy 51:18-26.

O'Farrell, M.J., B.W. Miller, and W.L. Gannon. 1999. Qualitative identification of free-flying bats using the Anabat detector. Journal of Mammalogy 80: $11-23$.
Ports, M.A., AND P.V. Bradley. 1996. Habitat affinities of bats from northeastern Nevada. Great Basin Naturalist 56:48-53.

Rabe, M.J., AND S.S. Rosenstock. 2005. Influence of water size and type on bat captures in the lower Sonoran desert. Western North American Naturalist 65:87-90.

RACEY, P.A. 2009. Reproductive assessment of bats. Pages 249-264 in T.H. Kunz and S. Parsons, editors, Ecological and behavioral methods for the study of bats. 2nd edition. Johns Hopkins University Press, Baltimore, MD.

Rodriguez, R.M., AND L.K. Ammerman. 2004. Mitochondrial DNA divergence does not reflect morphological difference between Myotis californicus and Myotis ciliolabrum. Journal of Mammalogy 85:842-851.

Sikes, R.S., W.L. Gannon, and the Animal Care and Use Committee of the American Society of MamMALOGISTS. 2011. Guidelines of the American Society of Mammalogists for the use of wild mammals in research. Journal of Mammalogy 92:235-253.

Simmons, N.B., AND R.S. Voss. 2009. Collection, preparation, and fixation of specimens and tissues. Pages 849-867 in T.H. Kunz and S. Parsons, editors, Ecological and behavioral methods for the study of bats. 2nd edition. Johns Hopkins University Press, Baltimore, MD.

Skowronski, M.D., And M.B. Fenton. 2008. Modelbased automated detection of echolocation calls using the link detector. Journal of the Acoustical Society of America 124:328-336.

Szewczak, J.M., S.M. SzewCZaK, M.L. Morrison, and L.S. HaLl. 1998. Bats of the White and Inyo Mountains of California-Nevada. Great Basin Naturalist 58:66-75.

VAN ZYLL DE JONG, C.G. 1984. Taxonomic relationships of Nearctic small-footed bats of the Myotis leibii group (Chiroptera: Vespertilionidae). Canadian Journal of Zoology 62:2519-2526.

Verts, B.J., AND L.N. Carraway. 1998. Land mammals of Oregon. University of California Press, Berkeley, CA.

Received 11 February 2016 Accepted 9 September 2016

Appendix 1 on page 508 . 
Appendix 1. Coordinates and elevations of water sources where bats were sampled at Desert National Wildlife Refuge, Nevada, 2008-2014, with associated land cover types (Lowry et al. 2005), dates of sampling, species, numbers and sexes of captured bats ( $\mathrm{ND}=$ sex not determined).

Black Rock Hills Gap (incidental terrestrial capture, no mist-netting; 36.569080 N, 115.356730 W, elevation $1310 \mathrm{~m}$ ). Mojave Mid-Elevation Mixed Desert Scrub, North American Warm Desert Bedrock and Cliff Outcrop. 16 Apr 2014. P. hesperus (10).

Corn Creek Visitor Center pond (36.43888 N, 115.35857 W, elevation ca. 898 m). Sonora-Mojave CreosotebushWhite Bursage Desert Scrub and North American Warm Desert Riparian Mesquite Bosque. 19 Jun, 16 Aug, 28 Aug

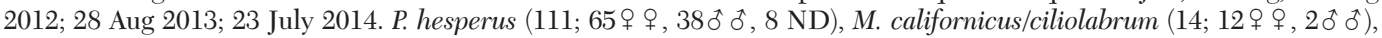
E. fuscus $(3 ; 1 \uparrow, 10,1 \mathrm{ND})$, A. pallidus $(2 \uparrow q)$, M. volans $(1 \%)$.

Desert Lake Camp (incidental terrestrial capture, no mist-netting; 36.921260 N, 115.292240 W, elevation 1096 m). Sonora-Mojave Creosotebush-White Bursage Desert Scrub, Mojave Mid-Elevation Mixed Desert Scrub, and InterMountain Basins Semi-Desert Shrub Steppe. 19 Apr 2014. P. hesperus (1 9 ).

Mormon Well Pass Spring (36.64420 N, 115.09724 W, elevation 1972 m). Great Basin Pinyon-Juniper Woodland.

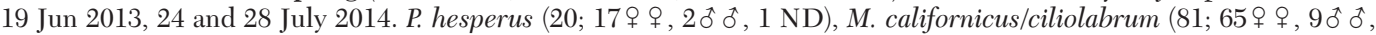

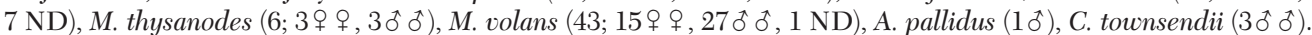

Quail Spring “drinkers” (36.45362 N, 115.13876 W, elevation ca. 1606 m). Mojave Mid-Elevation Mixed Desert Scrub. 10 Apr, 27 July 2014. No captures.

Rye Patch Spring (36.57961 N, 115.30592 W, elevation 1890 m). Mojave Mid-Elevation Mixed Desert Scrub, Great Basin Pinyon-Juniper Woodland. 5 Aug 2012. M. californicus/ciliolabrum (2; 1 , 10ิ), M. thysanodes (1 + ), M. volans $\left(3 ; 2\right.$ 우, 1 $\left.\delta_{)}\right)$, M. yumanensis $(1+)$.

Sawmill Spring ( 36.68050 N, 115.17955 W, elevation 2560 m). Rocky Mountain and Great Basin Lowland and Foothill Riparian Forest, Southern Rocky Mountain Ponderosa Pine Forest and Woodland. 17, 18 June 2008. C. townsendii

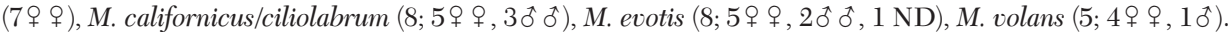

White Sage Gap “drinker” (36.72211 N, 115.37416 W, elevation $1257 \mathrm{~m})$. Mojave Mid-Elevation Mixed Desert Scrub, Sonora-Mojave Creosotebush-White Bursage Desert Scrub. 14 Jul 2013. P. hesperus (31; 23 q $q, 60 \hat{~ o ̂, ~} 2$ ND), M. californicus/ciliolabrum $(18 ; 15$ 우, $3 \hat{0} \widehat{0})$, M. thysanodes (3우).

White Spot Spring (36.43024 N, 115.20997 W, elevation ca. 1366 m). Mojave Mid-Elevation Mixed Desert Scrub. $1 \mathrm{Jul}$ 2013, 7, 8, 12 Apr and 22, 28 Jul 2014. P. hesperus (57; 37우 , 17 ô ô, 3 ND), M. californicus/ciliolabrum (34;

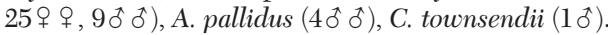

Wiregrass Spring at Hidden Forest (36.63324 N, 115.20866 W, elevation 2433 m). Rocky Mountain Montane DryMesic Mixed Conifer Forest and Woodland, Great Basin Pinyon-Juniper Woodland. 18, 19 Aug 2009, 25 Aug 2014. C. townsendii (1 ND), M. evotis (4; 10, 3 ND), M. volans (3 ND), P. hesperus (2 ND). 